\title{
The unity of the church
}

\author{
Henk DeWaard \\ Reformed Theological College \\ Geelong Vic. 3220 \\ AUSTRALIA
}

The New Testament speaks consistently of the Church as being one. The classic New Testament passage that speaks on the unity of the Church is found in John 17, though it is by no means the only passage. Certain aspects of 'the unity of the church' are touched on in this paper. Each of the points made, however, warrants further elaboration.

\section{IMAGERY OF THE BODY}

The New Testament broadens the picture with the imagery of the body which has many members, all of whom are needed and all of whom contribute to the proper functioning of the whole body. The term body of Christ is used without the definite article to indicate that the local church is never the total body of Christ. Rather it is a manifes tation of the one, universal Church. In the local church, the new people of God is represented. In 1 Corinthians 12 Paul points to the interdependence of the members who are responsible for each other. This same mutual dependence and fellowship (in the knowledge and salvation given in Christ) is expressed in the images of a household and brotherhood (1 Peter 2:7, 5:9; Ephes. 2:19). The church is bound together by an underlying, essential Gospel which binds the members together (Romans 1:1; Col.1:26; Acts 28:31; 1 Cor. 15:1-3). Fellowship between members and between churches is in truth (Gal. 1:8,9).

Over against attempts at syncretism in the Colossian church, Paul emphasized the allsufficiency of Christ. Real unity is in Christ: Ephesians 4:15,16. Unity is not primarily doctrinal or organizational, though these things are important.

This imagery of a body and household is not just a description of the relationship of one individual member of the congregation to others. There is a wider dimension: we see this expressed in the gifts of food sent from one Church to another, in the greetings exchanged between churches, in the mutual decisions on matters of dispute (Acts 15), the actions taken together and many other considerations. This mutuality between churches can be seen in such passages as Acts 11:27-30; 1 Corinthians 16:1-3; II Corinthians 8:9; Romans 15:25-27; Galatians 2:10. 


\section{UNITY AND TRUTH}

There is little problem with respect to the varieties of gifts to be found in the Church. People with different gifts can co-exist with each other to the enrichment of all. The problem arises when the New Testament indicates that there are some kinds of error that are not to be tolerated; some kinds of belief and behaviour require that 'the other' be treated as a heathen and publican. In other words, there are situations when judgment is to be passed on words and deeds which may be so serious as to require excommunication. 1 John 4:2,3: "Every spirit that acknowledges that Jesus Christ has come in the flesh is from God, but every spirit that does not ... this is the spirit of the anti-christ."

The church has drawn from these scriptural injunctions the principle that fellowship is not to be exercised with those who deny basic doctrines of the faith. What are the basic doctrines that require repudiation of fellowship? What are the identifying, fundamental Christian truths that are necessary for unity?

\section{ESSENTIAL AND NON-ESSENTIAL DOCTRINES}

There should be little question that a distinction should be made between essential and non-essential doctrines and that fellowship should be maintained with all those who agree with us in essentials. The great leaders of the Christian Church have all been in agreement with this. John Calvin once wrote to the refugee church in Strassburg that they should not disrupt the unity of the Church over a candle. He was willing to accept some kind of episcopacy in the Church provided the bishop would subject himself to the Word of God. When shown the Second Prayer Book, he wrote back to one of the Puritans: "In the Anglican liturgy ... I see many tolerable stupidities." He recommended that they be endured for a time. In the fourth book of the Institutes he expressed himself as willing to maintain fellowship with the Catholic Church itself, provided the essential doctrines of the church be maintained.

The real question is how these essential doctrines are to be determined. The early Church found two devices helpful in this respect: to listen to the bishop who was supposed to be the successor to the apostles and to follow the formulation of the Creeds. In the profusion and confusion of modern differences within the Church these do not prove easy solutions to work with. Even in episcopal Churches the bishops differ among themselves and in the Roman Catholic Church it is necessary to fix final responsibility in one man who has shown himself fallible like the rest of us.

The Ecumenical Creeds also fall short. It is good to rely on these Creeds; and we might be greatly surprised how much we share together with Roman Catholics in certain key areas and how far they separate us from some Protestants. But there are many issues which have arisen since these Ecumenical Creeds were written on which they have nothing to say. 


\section{REFORMATIONAL CONFESSIONS}

An appeal to Reformational confessions will be helpful but wil not resolve all issues. In our world of imperfect understanding we should be careful with our anathemas and admit that we are unsure on many issues.

\subsection{Belgic Confession Article 29}

In this article of the Belgic Confession the true and false church are contrasted in terms of the marks of the church (the pure preaching of the Word, the proper administration of the Sacraments and the faithful exercise of church discipline). It goes on to say that by these marks the true and false church are easily distinguished. But where is that church?

Do jurisdictional or personality differences justify breaking fellowship? For example, in 1 Corinthians 3 we read of a party spirit in the church: "I am of Paul, I am of Apollos ...". Did such differences require an anathema? What do we mean when we affirm with the Nicene Creed: We believe one holy, catholic and apostolic church. We affirm that the Church is one (though we do not know exactly the shape of that unity), that it is holy, that it is catholic (universal) and that it is apostolic (interpreted differently by Catholics and Protestants).

While this Creed raises many issues, it also provides us with a vision which is so alien to many Christians. It is an article of faith which at the same time requires us to give visible expression to it. The Church is Christ's witness; his presence in the world. It is, however, a sad witness when the body is visibly divided. For the sake of Christ we must seek the visible unity of His body. This is not an option; it is a mandate! Even our opposition to the World Council of Churches (if we are opposed) does not absolve us from striving to express the unity of God's people. We must not be isolationists. We must engage in conversation with other Christians with whom we disagree on certain matters. This way of thinking is foreign to the narrow, denominational enthusiast who is uncertain whether anyone beyond his own group belongs to Christ. It is also foreign to the thinking of the fundamentalist who thinks exclusively in individual terms and has little appreciation for the Church. We do not strengthen our cause by taking on pseudo-Christians. But by all means let us have fellowship with all whom we may legitimately recognize as Christians. That too is a sign of faithfulness.

\subsection{The Heidelberg Catechism}

Another confessional document worth considering (at least from my background) is the Heidelberg Catechism (Lord's Day 21):

I believe that the Son of God, through His Spirit and Word, out of the entire human race, from the heginning of the world to its end, gathers, defends and preserves for himself a community chosen to cternal life and united in true faith. And of his community $I$ am and always will be a living member. 
The person who confesses this cannot hold that the church began with the emergence of the Anglican or Reformed Church in Reformation times. The church is gathered from the beginning to the end of time and is gathered out of the whole human race. Yet the tension is also felt here when the catechism says: "... united in true faith".

\title{
4.3 The Westminster Confession
}

Chapter 25 of the Westminster Confession speaks of the invisible church which is catholic or universal, consisting of all those throughout the world who possess the true religion, together with their children. And then it says:

\begin{abstract}
This catholic church hath been sometimes more, sometimes less visible. And particular churches, which are members thereof, are more or less pure, according as the doctrine of the gospel is taught and embraced, ordinances administered and public worship performed more or less purely in them.
\end{abstract}

The purest churches on earth are subject to mixture and error.

\section{DOES DOCIRINE DIVIDE?}

We all realize that in the real world of daily congregational life, the above questions are not perceived as vital and urgent. For many, doctrinal questions are irrelevant. Sometimes this is true of persons in leadership positions. The idea that doctrine divides is not dead. Some church mergers take place with scant regard for doctrinal considerations. In some circles connected with the World Council of Churches it is increasingly difficult to get a hearing for matters of doctrine. Among pietistic and fundamentalistic Christians there is equal disregard for doctrine. 'I don't care what a person believes, as long as he has fire in his belly', is a frequently implied notion. In these circumstances it is necessary to remind ourselves that the Bible says: "And you shall know the truth and the truth shall make you free" (John 8:32).

However, it is a sad fact that precisely those who have a high view of bibical truth are often least concerned about ecumenical matters. This is unfortunately true of some Reformed/Presbyterian churches:

In the midst of a world torn into conflicting groups, we find the churches fighting one another with equal ferocity ... The Reformed tradition is known par excellence for its lack of love and tolerance, for its emphasis on doctrinal purity at the expense of the pure doctrine that the church shoud be one. (Prophetic witness in bewildered world: REC Missions Conference Papers, 1981:34.)

\section{CONCLUSION}

There is something to be said for the practice of fellowshipping and working with brothers and sisters of other denominations as long as there is no justifiable fear of being implicated in gross error. A great discovery sometimes awaits us when we see that the positions ascribed to persons of another family of Christians are inaccurately 
pictured or do not mean what we have always thought they meant. We may discover that there is indeed a unity which we did not know existed. If we can discover this at the grassroots level so much the better! 
